\title{
Model of Learning Activities for Improving Life Quality of the Elderly Using Elderly School as Base
}

\author{
Phackaphon Salathong ${ }^{1}$, Rawiwan Thoranee ${ }^{2}$ \\ ${ }^{1,2}$ Lecturer, Faculty of Liberal Arts, University of Technology Phra Nakhon, Thailand \\ ${ }^{1}$ phackaphon.s@rmutp.ac.th, ${ }^{2}$ rawiwan.t@rmutp.ac.th
}

\begin{abstract}
This research has the objective to analyze the learning activities and format of the activities to develop life quality of the Elderly using school as base. This is intended to collect data from in-depth interviews, discussions as well as observation and field reporting to analyze data content oriented and descriptive from actual occurrences. Results of the survey finds that learning activities to develop life quality of the Elderly adopts for consideration the following: 1) background of the school for the Elderly, 2) objective of knowledge management, 3) content or course outline to teach within the school for the Elderly, 4) format, process and method of knowledge management, 5) evaluation or monitoring regarding the format of activities for knowledge which finds that there are 2 characteristics namely 1 . format of activities for knowledge management in the form of institution with course and syllabus, and 2. format of activities for knowledge management in the form of rural which select the attendees while the form of teaching is showing to set as sample to follow.
\end{abstract}

Keywords

Learning Activities, Quality of Life of the Elderly, the Elderly School

Article Received: 10 August 2020, Revised: 25 October 2020, Accepted: 18 November 2020

\section{Introduction}

"Elderly Schools" is another form that realizes the value, importance and power of elderly people through the role of rural and community taking part in managing for the elderly people to have crucial knowledge and understanding to maintain life (Naewna Online, 2019) [1] as well as promote lifelong learning, development of skill and improve the life of the elderly to be Active Aging together with improving the elderly's life quality, both as individual and social. It is hoped for happiness to improve both at soul and in the heart with the feeling of security in life and feeling being a part of the society. This is an option to prepare for readiness as we fully enter into the elderly society since Elderly Schools will help the elderly open the opportunity to learn and take art in activities with the community along with opening the chance for elderly people to meet and talk, exchange experiences, share know-how accompanied by improving oneself in every way. With this, the elderly people will see the value within oneself, arise self-pride, reduce burden of the society and further increase social energy. (Department of Elderly Affairs, 2017) [2]

Presently, there are a variety of Elderly Schools in terms of location, system of education and methods or activities. Hence, it all depends on the condition of the area and the demand of the elderly people as well as the sponsoring state agency. According to the result of educational studies and various offices, it was found that Elderly Schools are educational institutions or agency or community that arranges activities to develop elderly people through systematic transfer of knowledge which elderly people learn with entertainment. Elderly people who become students through schools are developed with skill in taking care of oneself, controlling oneself and are able to depend on oneself (Sasipat Yodpetch, Pawana Patanasri and Thanikarn Sakdaporn, 2017). [3] On top of Elderly Schools playing an important role in developing elderly people's life quality, local community is also the major source to support lifetime learning and is the area to interact in social and promote self-value to the elderly people in parallel with being the presence for well-being to perform activities in healthcare, polishing skills, using technology, participating in recreational activities as well as seeking various knowledge (Pinwadee Srisupun, Suree Thamikbaworn and Surasom Krisanajutha, 2017). [4]

From the mentioned, Research is interested in further studying about the format of activities in learning for development of Elderly People's life quality using Elderly Schools as base. However, to further explore about learning activities and the system of learning activities on how to improve Elderly People's life quality, this research paper will introduce areas in the society for Elderly People to perform and pull out highest capabilities out of the Elderly People for best benefits to both the individual elderly person and to the society as a whole. This is so that Elderly People will be able to take care of themselves at old age with quality and be able to progress into developing positive behavior within the elderly person to consist of good health, take part in the society and have assurance that is solid and sustainable including being beneficial to personnel relating to further improving life quality of Elderly People.

\section{Literature Review}

Elderly Schools is one of the ideas to promote effective lifetime learning process for Elderly People so they can learn and improve their skills in taking care of themselves which will lead to improve the quality of life of Elderly People. This is based on the principle that Elderly People are worthy and capable and should be promoted to take part in benefitting the society as well as promoting knowledge that links to past experiences of the Elderly People. The core of knowledge must be that which the Elderly People deem useful to be brought to apply is their present everyday living 
(Department of Elderly Affairs, 2017) [2] Therefore, the principle of knowledge management for Elderly People is fulfilling the compulsory need and requirement of knowledge, yet, to satisfy the need to know and see and the urge to do activities to exchange interest with other members. Generally, this is knowledge outside the system that is planned knowledge joined amongst Elderly People together with the organizer. Generally, there are many systems and methods that varies differently according to the demands of the Elderly People and the process of managing learning activities which should be based on the foundation of (1) background, (2) purpose of learning, (3) content of knowledge, (4) system or method of learning, and (5) evaluation or results that may occur. Moreover, knowledge management for Elderly People should also consider the demands, experience and nature of learning the Elderly People as well as the importance and creation of learning atmosphere (Suchada Jukpisut et all, 2005) [5] and (Archaya Ratana-ubol, 2019). [ 6] For that reason, knowledge management for Elderly People must consider the need and quality of life in all dimensions of the society as well as appropriate assurance and security upon depending on oneself ( National Elderly Committee, Ministry of Social Development and Human Security, 2010) [7]. Research Paper of (Pinwadee Srisupun, Suree Thamikbaworn and Surasom Krisanajutha, 2017). [8] stated that development of life quality for Elderly People in the community through Elderly Schools found that Elderly Schools has an important role in developing life quality and is the source of support for life-time learning as well as being the grounds for social interaction, promote value for Elderly People and is the area for happiness through activities to take care of the health, practice skill for profession, apply technology, be involved in recreation activities as well as seek for other knowledge. At the same time, Sasipat Yodpetch, Pawana Patanasri and Thanikarn Sakdaporn (2017). [3] mentioned that Elderly Schools have the characteristics of activities that institutions or communities form up to develop the capabilities of Elderly People through systematic transfer of knowledge with happiness and delight. Students who go to Elderly Schools will improve in skill of taking care of oneself, selfcontrol and become more dependent on oneself. Office of the Education Council, Ministry of Education (2018) [9] elaborated the design of activities for learning must consider about development of life quality of Elderly People in 4 dimensions namely body, spirit, wisdom and social and reflect on the type of problem and the need of Elderly People in each area which may differ in terms of way of living, income, health, background, education and work. In summary, Elderly Schools is one of the institutions which have an important role in developing the quality of life of Elderly People as well as being another source for life-time learning which arranges knowledge to fulfill the need for more knowledge and have involvement to improve the 4 dimensions namely body, spirit, wisdom and social.

\section{Method}

This research is done in the form of Qualitative Research using Case Studies that focus on in-depth and understanding of actual happenings (Christensen, L.B., Johnson, R.B., Turner, L.A., 2015) [10] of the Elderly People group participating in learning activities of the School for Elderly People in the areas of Suphanburi, Kanchanaburi and Bangkok provinces since there are model of learning activities namely School for Elderly People at Tambol Plubplachai at Amphur Uthong, Suphanburi province, School for Elderly People at Tambol Nonglan at Amphur Tamaka, Kanchaburi province and School for Elderly People at Yannawa District of Bangkok Metropolitan. All these 3 School for Elderly People are Paradigmatic Case that reflect the learning activities, acceptance in social or community as well as prize winning and certificate issuance for various areas from sources of learning that has offices who come to constantly observe. This is the reason why these 3 schools are being selected as models for this research as well as being reachable and research can be performed continuously.

As for proceedings, work is done in 2 stages namely the first stage is In-depth interview relating to learning activities for development of life quality of Elderly People using Elderly School as base. Here, 15 people is selected as Purposive Sampling that consists of staffs that are involved in the School for Elderly People and students who are elderly people that comes to participate in the learning activities of the school. Second stage is Focus Group Discussion relating to the learning activities for development of life quality of Elderly People which is seeking for details to summarize the learning and format of activities that is correct and corresponds with the representative of the elderly people and related personals, totaling 12 people namely staffs of the School for Elderly People, Head of community and relatives of the elderly people that have been selected for surveying and take part in this group discussion. As for analysis of data, analysis is done in the form of context and uses the method of Strauss and Corbin (1990) [11] together with report in the table format (Miles and Huberman, 1994) [12]. Overall, the result is presented in a report format with wordings to emphasize each elaboration.

\section{Results}

Part 1: Analysis the learning activities for development of life quality of Elderly People using Elderly School as base, studies found that: Area No.1 Background of the school for the Elderly can be concluded that establishment of Elderly School derived from any original thoughts from the National Elderly Plan No., 2 (2002-2021), Amended No.1

2009), where one idea that is alike is the promotion of lifetime learning process for Elderly People increase their capability to support their learning and skill development in taking care of themselves which in turn will also improve the quality of life of the Elderly Person, Area No.2 Objective of knowledge management in general found that promotion of knowledge management and development of oneself, protection and preserving right of Elderly People, promoting good health both for the body and spirit together with letting Elderly People create benefit to the community and society, Area No.3 Content or course outline to teach within the school for Elderly People finds that each school for the Elderly People operates in accordance with the manual to operate Elderly Schools. Therefore, course taught within the School for Elderly People have the objective for Elderly People to learn at their free-will, happiness, 
entertainment and stresses on development of various skills are required within the area, Area No.4 Format, process and method of knowledge management finds that Schools for elderly People are managed and administered in terms of learning in the form of a committee consisting of people within the community or area and some areas also consisting of external people as well. Mostly, Schools for Elderly People are established by state offices i.e. Tambol Administration Office and some schools are established by private offices or foundations so committee members vary from advisors to the Schools for Elderly People namely monks or related officers in the area, and Area No.5 Evaluation or monitoring regarding the format of activities for knowledge finds that there are similarities and difference depending on intentions of each area. Mostly, the vision and mission of Schools for Elderly People do not focus on evaluation or monitoring the results in theory but give importance to the outcome that could be observed empirically as the course determines and concentrates on actual knowing, actual performance and the ability to transfer knowledge. As for activities for learning to develop Elderly People usually comes in courses i.e. course in academic, rights and law, health and profession or way of living and changing society. Hence, some schools also contain course that are easy to remember and have activities in areas of 1) What Elderly People must know, 2) What Elderly People should know and 3) What Elderly People want to know, all of which depends on the context of the area and administration and manage of each school.

Part 2: Format of activities for development of life quality of Elderly People using Elderly School as base, studies found that arranging the process for learning in individual School for Elderly People have different focus depending on the area where they are located. Each school is derived from the same basis of H-T-S (Home-Temple-School). Apart from this, the main emphasis is managing the system for learning to be in the format with students and with teachers or inviting those with knowledge to give knowledge or demonstrate or become joint teachers with attendants being checked, hours of attendants being collected and collected data becoming part of the evaluation and monitoring results after learning. As for the activities for learning of each School for Elderly People, mostly give emphasis to development of life quality of Elderly People under the concept of developing life quality for the body, spirit, social and wisdom. There are 2 characteristics for activities of learning, namely 1 . Format of activities for knowledge management in the form of institution with course and syllabus where teachers or instructors come from the network within the area or community through live telecast or teach through other means of teaching for activities that involve teaching to villagers or activities that require show-to-do be become sample to follow i.e. activities to develop a career and increase income, activities involving personal happiness or knowledge regarding savings, knowledge about food, making herbs and agriculture. It is further known that activities for learning has the following formats of (1) format for learning on the grounds of things required to know to maintain life and world society at present, (2) format for learning on the grounds of benefits, protection and rights as Thai citizens, and (3) format for learning on the grounds of general knowledge required to know or wanting to know knowledge based on learner's requirements or knowledge on way of life of the learner or knowledge on local culture. As for evaluation and monitoring for Schools for Elderly People is different i.e. some stress on hours of class attending since they wish to focus on discipline and self-training to have responsibility in being involved the various learning activities as determined by the School for Elderly People. Furthermore, testing and measurement of knowledge is not found with students of Schools for Elderly People since there is no necessity and does not correspond with the intention to establish Schools for Elderly People in each area. Yet, another problem regarding activities for elderly learning is found in 2 aspects namely (1) internal factors i.e. the problem of the method that brings about the activities for learning that does not link between the context or knowledge with the vision and mission of the school and (2) external factors i.e. the lack of support from agencies that have direct role for continuous care like the educational or career development offices.

\section{Conclusion}

Learning activities for development of life quality of Elderly People using Elderly School as base corresponds with the intention to establish Schools for Elderly People (National Elderly Persons Committee, Ministry of Social Development and Human Security, 2010) [7] that gives importance to living life and knowing and seeing the value of oneself. Here, foundation to support the learning activities and improving the life quality of Elderly People on the basis of involvement with local community and allied network. Further results finds that it corresponds with Pinwadee Srisupun, Suree Thamikbaworn and Surasom Krisanajutha, 2017). [8] that School for Elderly People take an important role in developing the quality of life of Elderly People in the community in addition to being the source to promote life-time learning, being the area to interact in society, support giving value to elderly people and is the grounds for happiness as well as performing activities relating to taking care of the health, skill practice, using technology, do recreational activities in addition to seeking for various other knowledge. Nevertheless, because every School for Elderly People have a role and target to clearly improve life quality, all activities have been designed to correspond to the demands of the elderly people with network in the area and Home-Temple-School (H-T-S) backing up. Activities mainly are in the form of institution determined courses and local/learner demand courses in accordance with the present intention of establishment of each School for Elderly People.

As for the format of the Learning activities for development of life quality of Elderly People using Elderly School as base matches to Sasipat Yodpetch, Pawana Patanasri and Thanikarn Sakdaporn (2017). [3] that Schools for Elderly People have the characteristics of activities that institutions or communities form up to develop the capabilities of Elderly People through systematic transfer of knowledge. Upon considering the details of the activities, it was found that the success factor for Schools for Elderly People consist of (1) the elderly people group, (2) administration and management, (3) learning activities and (4) network for 
development, which is in parallel to the principle of good promotion to effective life-time learning activity for elderly people for elderly people to have knowledge and be able to develop themselves under the care of the Department of Elderly Affairs. Based on the manual for Schools for Elderly People (2016), the key elements to successful operation of Schools for Elderly People are leadership, target and activities, participation, social network, continuous learning and development process and support from the state. Yet, each Schools for Elderly People being selected as model case study each have their success and can attain to be model of Schools for Elderly People when considering the related factors.

\section{Acknowledgment}

This research paper has been supported with the scholarship from the 2019 monetary budget of the Faculty of Arts, Rajamangala University of Technology Phra Nakhon. The researcher wishes to show appreciation to the group of Elderly People and all persons relating to the 3 Schools for Elderly People for the information and advice for this study to be most complete. Appreciation extends to all coordinators that guided on field to collect information as well as good cooperation from all related offices.

\section{References}

[1] Naewna Online (2017) 'School for Elderly People" Promote Energy for Retirees to Self-Care, Date of data search : 21 December 2017 from http://www.naewna.com/likesara/317964.

[2] Department of Elderly Affairs (2017) 'Manual for Schools of Elderly People', Date of data search: 14 December 2017 from http://www. dop.go.th/th/know/5/24.

[3] Sasipat Yodpetch, Pawana Patanasri and Thanikarn Sakdaporn (2017), 'School for Elderly People : Version on Knowledge and Development of Capabilities of Elderly People', Bangkok: Mata Printing Co., Ltd.

[4] Pinwadee Srisupun, Suree Thamikbaworn and Surasom Krisanajutha (2017), 'School for Elderly People and Development of Capabilities in Local Communities of the Northeastern Area', Volunteer Graduate Magazine 14(1) (Jul. - Dec. 2019), 133162.

[5] Suchada Jukpisut et all, 2005, 'Alternative Studies, World of Out-of-school Learning', Bangkok: Office of Research Support Funding.
[6] Archaya Ratana-ubol (2019), 'Promoting Learning for Adults and Elderly People in the Thai Society', Bangkok: Department of Lifetime Education, Faculty of Education, Chulalongkorn University.

[7] National Elderly Persons Committee ( 2010), National Elderly Persons Plan No.2 (2002 - 2021), Amendment No.1 (2009), Ministry of Social Development and Human Security, Bangkok: Thepphenwanis Printing.

[8] Pinwadee Srisupun, Suree Thamikbaworn and Surasom Krisanajutha (2017), 'School for Elderly People and Development of Capabilities in Local Communities of the Northeastern Area', Volunteer Graduate Magazine 14(1) (Jul. - Dec. 2019), 133162.

[9] Office of the Education Council, Ministry of Education (2018), 'Comparative Research Report for Policy Development on Learning Promotion of Elderly People in Thailand', Bangkok: Pikwan Graphics Co., Ltd.

[10] Christensen, L.B., Johnson, R.B., \& Turner, L.A. (2015). Research Methods, Design and Analysis, Global Edition. (12th ed.). United States of America: Pearson.

[11] Strauss, A., \& Corbin, J. (1994). Grounded Theory Methodology: An Overview. In N. K. Denzin, \& Y. S. Lincoln (Eds.), Handbook of Qualitative Thousand Oaks, CA: SAGE.

[12] Miles, M. B. and Huberman, A. M. (1994). Qualitative Data Analysis: An Expanded Sourcebook, 2nd Ed. Thousand Oaks: Sage. 